\title{
CIVILIZATION VERSUS NATURE
}

\author{
Abay K. Baigenzhin ${ }^{1}$, Yermek Kassymbekov ${ }^{2}$
}

${ }^{I}$ Chairman of the Board, National Scientific Medical Center JSC, Nur-Sultan city, Republic of Kazakhstan

${ }^{2}$ Honorary Worker of Education of the Republic of Kazakhstan

This work is licensed under a

reative Commons Attribution 4.0

International License

J Clin Med Kaz 2020; 6(60):04-20
As there is no inventor,

Who by drafting a machine,

Had not imagined his creation

To ennoble humans,

There is no machine

That did not bring the world

The most misery

And the new kinds of enslavement.

Maximilian Voloshin. The ways of Cain.
Humanity is still receiving the opposite effect from its inventions: artificial or radically modified habitats and food products created by it lead to pathologies, terrible diseases, mutations and other destructive consequences for life and health. Chemicalization of agriculture, genetic modification, synthetic building materials - slowly and surely kill earthlings, contribute to its degradation.

Who thought that the invention in 1907 of the first plastic based on a synthetic polymer that retains its shape when heated, and invention in 1908 of cellophane would lead to the fact that already in 1968 the consumption of artificial fibers in the world would exceed the consumption of natural fibers, earth landfills would overflow with plastic, and in the world's oceans "plastic soup" is growing horribly fast, a floating strip of garbage by weight several times larger than natural plankton. The largest accumulation of garbage (there are five of them), known as the Great Pacific Garbage Patch, is located in the North Pacific Ocean and contains 80 thousand tons of plastic, covering an area of 1.6 million sq.km, which is five times larger than the area of Germany. According to the UN, there are, on average, 13,000 floating plastic fragments per $1 \mathrm{sq}$. $\mathrm{km}$ of sea water.

Environmentalists argue that by 2025 the mass of garbage in the oceans may account for a third part of the biomass of all fish, and by the middle of the century it will exceed it. About 8 million metric tons of plastic are released into the oceans every year. Many marine life mistake plastic for food. More than $70 \%$ of sea fish contains microplastics in the digestive tract, which from them enters the human body. Scientists have verified that plastic is present in $94.4 \%$ of tested fresh water and soil. Animals on earth receive and accumulate plastic from water and soil in the body, which then enters the human body. A dead whale washed ashore in Indonesia had $6 \mathrm{~kg}$ of plastic debris in its stomach: 115 plastic cups, 4 plastic bottles, 25 plastic bags, two plastic slippers and over 100 small plastic items. On the continent of Australia, the situation with pollution by plastic bags was recognized as critical and required prohibitive measures.

\section{The road of civilization is paved with tin cans. Alberto Moravia}

"Your physics is worthless if it obscures everything else from you: the rustle of the forest, the colors of the sunset, the ringing of rhymes. This is some kind of truncated physics, emasculated, if you want. I, for example, do not believe in it ... Any isolation first of all testifies to limitedness. A physicist who does not perceive poetry or art is a bad physicist."

Lev Landau

"People today forgotten they are really just a part of nature. Yet, they destroy the nature on which our lives depend. They always think they can make something better. Especially scientists. They may be smart, but most do not understand the heart of nature. They only invent things that in the end make people unhappy. Yet, they are so proud of their inventions. What is worse, most people are, too. They view them as if they were miracles. They worship them. They do 
not know it, but they are losing nature. They do not see that they are going to perish. The most important things for human beings are clean air and clean water and trees and grass that produce them. Everything is being dirtied. Polluted forever. Dirty air, dirty water, dirtying the heart of men."

Akira Kurosawa.

In the 90s of the last century, large-scale commercial production of genetically modified organisms (GMOs) began, which began to be used in agriculture (plant growing, animal husbandry), in the food and pharmaceutical industries. GMO crops, living organisms, which have been given some useful properties with the help of genetic engineering manipulations. If a traditional breeder gets a plant with the desired properties in several decades, then a modern genetic engineer for this, and with a much better result, takes only a few years.

Some experts assessed this phenomenon as positive in terms of solving the problem of food shortages on the planet, because GMO crops had high yields and were not very sensitive to adverse environmental factors (sharp temperature fluctuations, weeds, pests, diseases, etc.).

Another part of the experts believed that biotechnological experiments with GMOs only lead to damage to the biological and genetic fund of mankind. And it soon became clear that GMOs negatively affect humans, including their reproductive abilities. By the beginning of the 2000s, it became clear that the GMO industry should, if not be banned, then at least put under national and international control.

In general, humanity has become involved in the process of genetic engineering experiments, which from the very beginning began to generate huge profits, but their long-term consequences are not properly studied. The "GMO economy" continues to conquer more and more countries and spaces, destroying agrotechnics, worked out by several civilizations for many millennia, with all the ensuing consequences for humanity in the near future. The flow of transgenic products is constantly growing.

Until recently, Stephen Hawking, expressing concern about the possible emergence of a "new kind of superman", believed that in the future, people having learned to change DNA, "will not be able to resist the temptation to improve their qualities, including memory, immunity and increase longevity."

In November 2018, the Chinese scientist He Jiankui shocked the world community with a statement about the first ever changing the DNA of an embryo and the birth of the first in history genetically modified twins, whose DNA was modified so that their bodies could withstand HIV infection.

The Chinese authorities have banned all research related to editing the DNA of the embryo, believing that it is illegal and violates ethical standards. And who will guarantee that such work is not carried out in quietness of laboratories in other countries.

"... What else will humanity strive for? Will we just enjoy the benefits, keeping hunger, pestilence and war on the leash and maintaining ecological balance? Perhaps this would be the most reasonable thing, but humanity is unlikely to do so. It is rarely content with what it has. The most common reaction of the human mind to triumph is not satisfaction, but a thirst for new triumphs. ... Success fuels ambitions, and humanity, inspired by its recent accomplishments, makes ever more daring plans. Unprecedented levels of well-being, health and tranquility (but not for everyone), as well as our past experiences and our values, suggest that immortality, happiness and divinity will be the next goals of humanity. ... Having risen above the bestial struggle for survival, we will try to raise people up to gods and turn Homo sapiens into Homo Deus.

... The twentieth century was the era of the masses. The armies needed millions of healthy soldiers, and the economy needed millions of healthy workers. ... But the era of the masses seems to have passed, and with it the era of mass medicine. As soldiers and workers give way to algorithms, at least some of the elites may conclude that there is no need to raise or even simply maintain the standard health of the useless poor.

It makes more sense to focus on perfecting a handful of superhumans. ... scientific discoveries and technological progress will divide humanity into a useless mass and a tiny elite of advanced superhumans "

Yuval Noah Harari. Homo Deus. A Brief History Of Tomorrow».

As it is remind of Friedrich Nietzsche, who introduced the image of the superhuman (German: Ubermensch) in Thus Spoke Zarathustra to denote a creature that in its power should surpass modern man as much as the latter surpassed the ape. The moment will come and humanity will use all its energy so that through its own self-destruction the superman will appear. This is the ultimate goal of mankind in Nietzsche's philosophy; his most perfect works contain the meaning of his existence.

Let's hope that humanity has enough wisdom and common sense to make the right choice. Mankind has always cherished dreams of real immortality; people have embodied their dream of eternal life in myths about immortal gods. But here it is necessary to clarify, as they say, some essential details. And the sciencefiction writer Frederick Paul said it well.

"They dreamed of unlimited longevity already in Ancient Babylon, Sumer, Egypt. But her majesty nature is strict and merciless, she acts everywhere according to the principle of necessity. All living beings are mortal - so nature needs it. What would life be like without changing generations? The same as the Earth without changing seasons. I am reminded of the favorite parable of the great scholar of medieval period Roger Bacon about a certain Sicilian plowman who found in his field a golden vessel buried in the ground, containing an excellent drink, an immortal gift from heaven, as the plowman thought. And he drank it and washed his face with it, and his mind and body changed excessively, and from a country plowman he became an errand boy for the king. Do we all long for such "immortality"?

"A human being is an animal that tends to rise to God, and most of our troubles are an inevitable side effect of our efforts to do so."

William Shakespeare

"The belief in immortality was born from the thirst of insatiable people recklessly taking advantage of the time that nature has given them.... One human life is enough for the wise, but a fool won't know what to do even with the eternity"

Epicurus.

The consequences of the genetic modifications of people are a huge danger to humanity and it is worse than an atomic bomb. The modified species will become a real threat to modern human civilization on Earth, where already in the XXI century two intelligent 
species of living beings may arise - ordinary genetically pure people and technically modified human hybrids, which may lead to the fact that systems with artificial intelligence will declare that neither have consciousness, and will require recognition of this fact.

Attempting to create man by eugenics will give rise to monsters. An incident in this scenario of the evolution of mankind is that the intellect and bodily organization will be artificially improved to the detriment of the soul, which is not subject to technology. The basic principle of the existence of intelligent life in the Universe is the soul. Personal development should be an internal need, not a mechanical stamp. Only an equitable society is able to solve this problem.

Will it not happen literally in the coming years that biotechnology and artificial intelligence will finally prevail over a person, and then, at their own discretion, will change the minds and bodies of a person, rebuild society and the economy in a new way?

Each step in the field of knowledge must correspond to the same degree of self-restraint, the highest responsibility, otherwise new scientific discoveries can bring thousands of years of slavery, poverty and violence for humanity.

That's really unreasonable inquisitiveness.

I would not like to get acquainted with information materials of the following content in the future.

The capabilities of artificial intelligence have surpassed human capabilities many times over.

The rapid development of nanotechnology has passed into an uncontrolled stage.

The reproduction and programming of the machines of nanomachines is arbitrary.

Artificial Intelligence arbitrarily distributes the human mind between his physical body and the Internet.

There were many local civilizations, empires, states on Earth, which disappeared due to various reasons, including natural ones. Time passed, and the moment inevitably came when, due to various reasons that determine the strength of the state, morality fell sharply in society, satisfaction of deficiency needs succeed, injustice took grotesque forms, and as a result, a single whole turned into a mechanical set of units. And kingdoms, empires, republics collapsed. Although people are given knowledge, but often this knowledge is used to gain power over their own kind, and to materialize their desires, which have been growing from time to time. This is the human choice towards the animal nature. Only a few manage to use this knowledge for their spiritual development. This is observed in today's civilization, where a person is in bondage to his pernicious passions. If humanity does not radically change its priorities in thinking and behavior towards the spiritual, then the current (socalled industrial and postindustrial) global civilization is not yet 100 years old, which is nothing compared to the life of the planet and the stars, the sad fate of previous civilizations awaits, after which it is unlikely to recover.

«...The unreliability, laziness and naughtiness of "boys" and "girls" at every sort of jobs is characteristic of this very time. I call this the 'immorality explosion' and it seems to me more dangerous than nuclear war.

...All destruction of empires, states and policies came through moral depravity. This is the only real cause of ruin in all history and therefore destroying is the only self-destructions we became aware of with nearly all diseases.

When all men accustomed to honest and hard work [have] passed away what sort of a future awaits mankind? ...
Generations conditioned to the honest way of life must be extinct during the next twenty years and then a greatest disaster in history will come of widespread technical monoculture, which basically now persists in all countries...».

From the last letters of I.A. to Professor E.K. Olson. 1971; M .; RAS, 1994; 180-190,191

\section{Part seven}

In its development, at the first stage, a human took so little from nature that it could quickly restore what it had taken without loss. During this period, the balance of the exchange of matter and energy between nature and human society was still developing in favor of nature, which, if it became impoverished, then very slowly. Human could still be carefree in his relationship with nature.

\section{"Nature provides enough to satisfy natural needs." Lucius Annaeus Seneca}

The second stage began when in connection with the industrial revolutions, the balance of the exchange of matter and energy was sharply disturbed. Mankind began to take from nature more than it can restore, or so much that the main stock of natural resources - the potential "capital" of nature began to visibly decrease and disappear.

During this short period of time since the beginning of the industrial revolutions, mankind has repeatedly and variedly disturbed the ecological balance of the planet. The natural resources of the planet Earth are melting before our eyes.

Over the years, mankind has used nature's resources to build cities and roads, provide food and produce food. Since the 70 s of the XX century, the situation has changed dramatically - humanity has crossed a critical threshold. Since then, human consumption of biological resources has become ahead of what the planet can reproduce. If we compare the biocapacity of the Earth (the planet's ability to recover and absorb waste, including carbon dioxide) with the human ecological footprint (human consumption of renewable resources), then every year the rate of devastation is growing rapidly.

The World Wildlife Fund (WWF) notes that humanity does not give the planet Earth the opportunity to restore the disturbed nature's balance.

The so-called "Ecological Debt Day" or Earth Overshoot Day - the date when humanity's need for environmental resources and services in a given year exceeds what the Earth can restore this year, in 2000 came in the month of October, then in 2019 it moved for the month of July. Humanity has begun to consume renewable resources, $60 \%$ more than can be renewed, which is equivalent to 1.6 planets like Earth. If the ecological footprint remains the same, then by 2030, two planets like Earth will be needed to meet the needs of humanity.

In 2020 Ecological Debt Day reached on August 22, which, compared to July 29, 2019, seems like a step forward, but this is not cause for joy. Yes, indeed, the ecological footprint of mankind has decreased by $9.3 \%$ compared to last year, but this was not done intentionally, as a result of the rational selfrestraint of mankind, but as a result of the coronavirus pandemic, which slowed down economic life on Earth.

Overconsumption of the planet's resources by mankind leads to environmental degradation, resulting in desertification, a decrease in biological diversity, depletion of the rich soil layer, and environmental pollution.

Humanity needs to either reduce its needs and requirements for nature, or after calculating the overall balance of its material 
and energy "exchange" with nature, consciously go to a more systematic regime in the use of natural resources that is consistent with the rhythms of recovery processes, and at the same time apply various measures that would provide an increase in the restorative forces of nature and a general increase in its resource potential.

"The progress of humanity is based on the desire of every person to live beyond their means."

\section{Samuel Butler}

"Civilization in the true sense does not consist in the multiplication of needs, but in the free and wellthought-out restriction of one's desires.

It took Britain half the resources of the planet to achieve this prosperity. How many planets will a country life India require».

Mahatma Gandhi

At present, humanity is faced with acute environmental problems associated with the destruction of many species of plants and animals, pollution of natural waters, soil and atmosphere, impoverishment of landscapes, desertification, depletion of mineral and water resources, destabilization of weather and climate...

The sixth mass extinction of animals is caused not by natural causes, but by the activities of mankind, which cause irreparable damage to the environment. If nothing changes, populations will continue to decline, leading to the extinction of wildlife and jeopardizing the integrity of the ecosystems on which we all depend.

"The world is amazing. An inanimate body does not feel pain, and animals support the life of already intelligent beings people...

The God put a man on two legs so that he was tall, He has placed man's head high so as to enable him to behold the surrounding world, gave two hands for work.

Human does not crawl on all fours, as the beasts do, to get his food, but brings it to his mouth with his hand... Does this not testify to God's love for man? But if someone loves you, are you not obliged to reply in kind?

Just stop to think: the Sun sucks up moisture and turns it into the clouds that let fall the life-giving rain for seeds, grasses and flowers which gladden the human eye and heart; all kinds of fruit and sugar cane ripen to sustain life upon the earth; the rivers that flow into seas and lakes quench the thirst of birds and beasts and serve as the home of fish. The Earth is the giver of bread, cotton, hemp, fruit and berries; its bowels contain mineral wealth; birds provide man with down, eggs and meat; livestock give milk, wool and hide. The waters yield fish, the fish caviar, the bees - honey and wax, the silkworms - silk. Flowers placate people with their scent...

... No, the God did not make people sovereign masters of the Earth, He only made sure that their food was not transferred and that life could not end..

... The God kept humankind from exterminating animal species out of sheer greed and from harming succeeding generations.»

Abay. Words of edification. Word Thirty-Eight.

Over the past century, hundreds of unique and valuable animal species have disappeared from the face of the planet forever. As species disappear, ecosystems are destabilized and food chains are destroyed, which affects the survival of absolutely all living things on the planet, including humans.

Since the beginning of the appearance of Homo sapiens on Earth, two out of ten thousand species of mammals have died out every hundred years. Over the past 500 years, almost 900 species of living organisms have disappeared. Of these, 80 species of mammals. Previously, the decline was at a rate of 2 species per million years. Violent human activity in the 20th century has dramatically increased the rate of extinction of vertebrates on the planet. Species began to disappear 100 to 114 times faster than it was before the active intervention of people in the Earth's ecosystem. During this period, 468 species of vertebrates became extinct, including 69 species of mammals, 80 species of birds, 24 species of reptiles, 146 species of amphibians and 158 species of fish. Species that have disappeared from planet Earth over the past century would have become extinct in a world without humans in 11,400 years. The rate of extinction of animals on Earth, noted in the last century, coincides with those that were 65 million years ago, when dinosaurs, marine reptiles and pterosaurs disappeared from the planet.

On the verge of extinction were 40 percent of amphibians and 25 percent of mammals, and within the next two generations, 75 percent of the existing species will become extinct, while life on the planet depends on their diversity. The loss of each species plays a negative role in the ecosystem and undermines the capabilities of the Earth.

Today, only 4 percent of the species of living organisms live on Earth from all those who have inhabited the planet for billions of years.

According to scientists from the World Wildlife Fund (WWW), the world's populations of animals, birds and fish have decreased by 68 percent over the past 50 years due to human activities. This is stated in the calculation of the Global Living Planet Index - 2020.

The significant losses (94 percent) are incurred by populations of wild species found in Latin America. In Africa, populations declined by 65 percent, in the Asia-Pacific region by 45 percent, in North America by 33 percent, and in Europe and Central Asia by 24 percent.

As the World Wildlife Fund (WWF) notes: "Science confirms that we have brought forests, oceans and rivers to a state of disrepair. The rate and scale of decline in populations and wild habitats is increasing, which is evidence of our colossal impact and pressure on the planet, undermining the source of all our life - nature and biodiversity."

If this continues, then life will have to spend many millions of years to restore the lost biological diversity. And how important biological diversity is for nature can be seen from the following example.

«When in 1995 fourteen wolves were released into the wild in Yellowstone National Park (USA), scientists did not even suspect that this would radically change the entire ecosystem of the park.

There were no wolves in the park for 70 years and all this time elks reigned there, which over the years of uncontrolled reproduction (all efforts of people to control their population did not bring success) caused severe damage to the local flora. Fourteen wolves, of course, could not eat all the elks, but they forced those to be more careful in choosing places for grazing and to avoid certain parts of the park. In those places, vegetation began to revive. In six years, the number of trees has increased fivefold. Beavers have appeared, which need trees to build dams. Muskrats, ducks, and fish are in the backwaters. Wolves reduced the jackal population, which led to an increase in the 
number of hares and mice, and they attracted hawks, ferrets and foxes to the park. But the most amazing thing is that the wolves have changed the flow of rivers. Their channels straightened and stabilized, and coastal erosion decreased. This happened because the influence of wolves on deer led to the explosive growth of trees and grass along the banks of the rivers, which led to their strengthening. The geography of the park itself has changed, and all thanks to fourteen wolves. The return of wolves to Yellowstone National Park has had an unexpected side effect - the number of grizzly bears in its territory has increased, as the number of blueberry bushes and other berries that bears eat in the park increased, ecologists say in an article published in the journal of Animal ecology».

"In nature, everything is wisely thought out and arranged, everyone should do his work, and this wisdom is the supreme justice of life».

Leonardo da Vinci

Destruction of the environment occurs and sharply intensifies. Over the past 200 years, the world's forest area has halved. Forests currently cover almost 31 percent of the land surface and occupy about 4 billion hectares. Forests play a central role in the carbon exchange between terrestrial ecosystems and the atmosphere. Three quarters of all fresh water in the world comes from forest areas. About 12 million hectares of forest disappear from the face of the earth each year, contributing to an additional 11 percent of global greenhouse gas emissions.

Land resources, soil cover, forests are the basis of all living nature. This natural wealth has been created for millions, billions of years.

Currently, humanity cultivates about 11 percent of the total land area and 24 percent is used in animal husbandry. Only 35 percent of the world's land fund is agricultural land used by humanity for food production. The rest of the territory is mountains, deserts, glaciers, swamps, forests. Throughout the history of civilization, population growth was accompanied by the expansion of the "ecumene" in general and the area of cultivated land in particular.

Over the past 100 years, more land has been cleared for sedentary agriculture than in all the previous centuries of human existence. Now in the world there are practically no reserves for agricultural development, only forests and "extreme territories" remain. Land resources are rapidly decreasing: productive land is torn away for mining, absorbed by cities and other settlements, and flooded during the construction of reservoirs. Huge areas of cropland are being lost due to degradation, and destroyed soil is recovering very slowly. Under natural conditions, this takes more than one thousand years. Every year, due to erosion alone, 6-7 million hectares of land fall out of agricultural circulation, and due to waterlogging, salination, enleaching - another 1.5 million hectares. And although erosion is a natural geological process, in recent years it has clearly intensified, often due to imprudent human economic activity. At the current rate of erosion, the top fertile soil on Earth is being depleted at a rate of 7 percent per decade. Moreover, economic activity enhances this process (natural erosion) by 2-2.5 times. In the world, 24 billion tons of soil is lost annually due to erosion.

As well as erosion, the process of desertification of the Earth has been accelerated due to human fault. The total area of man-made deserts in the world is over 9 million square kilometers. Another $19 \%$ of the land is on the verge of desertification (the rate of desertification is 6 million hectares per year). Rapid population growth has led to a 4-fold increase in global food demand in the last 50 years alone, which aggravates many processes, increasing the burden on the planet's land fund. Up to half of the world's arable land is used to depletion, beyond reasonable utilization. The earth still provides the livelihoods of the world's population, but every year these opportunities diminish.

The supply of nutrients in the primitive soil increased as we moved from cold climatic zones to tropical ones; huge reserves of all nutrients necessary for plants were accumulated in their thickness. In tropical and subtropical regions with a large amount of precipitation, loess or red soil has formed. Warm sun, rich lands raised the jungle.

In the steppe and forest-steppe zones of the world, where there was less rain, but the necessary amount for the germination of a variety of herbaceous vegetation, for many millennia, there was an imperceptible work on transforming the grass into a fertile substance humus - the main organic matter of the soil containing nutrients necessary for higher plants. To the north, under the cover of forests, the creation of soils proceeded at a more moderate pace. Gray forest soils of varying degrees of podzolization with a gray interlayer resembling wood ash arose here. The acidic environment under the forest interfered, where the soils are often compacted, clayey, and coniferous litter contains many acids. Farther north, weak forest-tundra soils were formed; their development proceeded slowly due to cold weather, abundance of rains and a small fall of rare trees and grasses.

The variety of soils on Earth is amazing. Based on this, the lifestyle of the people living here was formed.

Earthly fertility is created by plants. Even before the appearance of human on Earth, they grew at the expense of the Sun and lenses invented by life, called chlorophyll grains, and settled in the leaves and stems of plants. Herbs created the primordial soil, they are the main healers of the earth, because they build their body by 93 percent from the air and energy of the sun and only 7 percent from the elements of the earth itself, i.e. constantly bring new energy and organic matter to the earth. The soil, as part of the biocenosis, is connected by thousands of threads with plants on it, with water in its horizons, with a nearby river and subsoil waters, with the sun. And man intervened in this biocenosis. The feeling of their unlimited power over the land, the desire to take from the land as much as possible and not compensate for the taken nutrients could not but lead to a weakening of the fertile beginning of arable land and meadows.

Scientists estimate that over the past hundred years, the amount of humus in the topsoil has decreased by 20-45 percent everywhere. Along with natural decomposition, the main thing is the loss of harvests without compensation for the harvest. We ate it with bread, potatoes, various cereals. A little more, and the sterility of the earth will begin.

Enriching ourselves, we ruin children and grandchildren.

Both land and sea, on which nearly 8 billion earthlings live, expect intelligent deeds and accomplishments from people. Nature has already swallowed plenty of poisonous fumes and stale waters, it is time to turn to the paternal shelter and build your home with the whole world in accordance with common sense.

Having relied on mineral fertilizers as a substitute for organic fertilizers, they made life easier for themselves without getting involved with manure. From the chain "sun-green leafhumus-soil-plant-organic matter), together with the harvest, organic matter is withdrawn, which does not return, and instead 
of it mineral fertilizers. The yield decreases, solar energy is not used properly in anemic leaves, and in the produced cereals, vegetables, fruits, etc., the proportion of nitrates exceeds all conceivable norms, having a detrimental effect on human health. In turn, the soil is steadily approaching the state of infertile soil.

«Major disasters, which have already ruined and continue to ravage the modern world, arise from human's unwillingness to reckon with the laws of nature, from his unwillingness to understand that hunger cannot be satisfied by devastating the earth.».

J. Dorst

Water is the cradle of earthly life, and in the near future the issue of drinking water will be the most acute for humanity. Water, in which there is no taste, no color, no smell, is not just necessary for life, it is life.

Water stands alone in the history of our planet. There is no natural body that could be compared with water in its influence on the course of the main, most grandiose geologic processes". There is no earthly matter - a mineral, a rock, a living body, which does not include it ... Water is the most important substance and controls dynamics of all life".

V.Vernadsky

There is a reduction in water resources, especially fresh water, which accounts for only 2.5 percent of the total volume of water on Earth.

If all the earth's water could be placed in a 5-liter canister, then even a teaspoon of fresh water would not be left in it.

According to the UN, the increase in freshwater consumption, caused, in particular, by demographic growth and population mobility, new needs and increased energy demands, combined with the tangible effects of climate change, are leading to growing water scarcity. Many countries have already reached their ultimate water use capacity. Freshwater consumption has tripled over the past half century, and irrigated areas have doubled over this period. More than 40 percent of the world's population suffers from drinking water shortages. Almost $80 \%$ of diseases in developing countries, which kill nearly 3 million people, are related to water quality.

Plants and factories, power plants consume large amounts of water and at the same time pollute it with various waste products. Rivers and lakes get sick, all living things die in such water

Extraction and processing of ores, manufacture of machines, etc. - all this requires a colossal amount of water, the lion's share of which goes away irrevocably.

And how much water is spent on serving mankind through the supplementary costs of goods used by mankind.

Supplementary costs of water for some goods

Rice: 3400 liters per $1 \mathrm{~kg}$.

Wheat. 1300 liters per $1 \mathrm{~kg}$.

Potatoes. 200 liters per $1 \mathrm{~kg}$.

Corn. 900 liters per $1 \mathrm{~kg}$.

Sugar. 1500 liters per $1 \mathrm{~kg}$.

Cheese. 5000 liters per $1 \mathrm{~kg}$.

Beef. 15500 liters per $1 \mathrm{~kg}$.

Lamb meet. 6100 liters per $1 \mathrm{~kg}$.

Pork. 4800 liters per $1 \mathrm{~kg}$.

Chicken meat. 3900 liters per $1 \mathrm{~kg}$.

Egg. 200 liters per $1 \mathrm{~kg}$.
Oil. 18 tons per 1 ton.

Steel. 230 tons per 1 ton.

Paper. 200 tons per 1 ton.

Passenger car. 140 tons per 1 unit.

Jeans. 6800 liters per 1 unit.

Cotton shirt. 1500 liters per 1 unit.

And the list is endless.

There is less and less clean water on Earth. The lack of it is already felt in many countries, which leads to a reduction in vital resources and a decrease in the area suitable for human habitation. The world now has 60 percent less fresh water available than it did 50 years ago.

Destruction of the environment occurs and sharply intensifies. The depletion of the ozone layer has caused global warming, disruption of the mechanisms to stabilize the planet's climate, intensification of hurricanes, floods, droughts and earthquakes.

UN Secretary General Antonio Guterres said that global warming did not slow down during the pandemic, and the concentration of greenhouse gases in 2020 reached a record level. "Yes, the economy has slowed down due to the pandemic, but the planet's overheating has not slowed down. As the report shows, the concentration of greenhouse gases in 2020 reached record levels.

He noted that the last time this concentration was supposed to have been "between 2.6 and 5.3 million years ago, in the Pliocene, when trees grew at the South Pole, and the water level was twenty meters higher."

Representatives of Greenpeace and WWF Wildlife Fund note: "The concentration of greenhouse gases continues to grow at an unprecedented rate, the global temperature is rising, and every year we see new temperature records, the actions of countries to switch to low-carbon technologies are insufficient. It is necessary to drastically reduce greenhouse gas emissions in all spheres of activity, in all sectors of the economy, including energy and transport, to abandon the use of fossil fuels and switch to renewable energy sources, switch to a circular economy and prevent waste generation, reduce emissions in rural areas, farm.

A large number of burial ground disposals are located around the world: radioactive, chemical, human waste. And if poisonous substances get into water-rivers, lakes, seas from ground soil, then there will be a collapse all over the world. The melting of ice and the global warming caused by this leads to the fact that around the world, in different geographical points, the climate is changing: somewhere there is a large amount of precipitation, and somewhere on the contrary, drought. As a result, the harvest dies."

The average temperature in the world has risen by $0.65^{\circ} \mathrm{C}$ since 1900. According to scientists, the Earth is currently warming up to its maximum value in the last 400 years. In the future, the world faces a temperature increase of at least $0.1^{\circ} \mathrm{C}$ per year, even if all greenhouse gas emissions were to stop today. Until 2100, it is predicted that the average temperature of the Earth will rise by $2.8^{\circ} \mathrm{C}$, which can lead to the melting of most of the world's glaciers, as a result of which the level of the world ocean will rise sharply and a huge part of the land will be flooded. Recent data show that sea level rise has been 1.8 centimeters since the $1990 \mathrm{~s}$, representing the worst-case scenario of the Intergovernmental Panel on Climate Change.

The global ozone depletion over the equatorial and mid-latitude regions in the years of low solar activity leads to additional heating of huge masses of water in both the Pacific and Atlantic oceans. Even in the Arctic Ocean, the average rate 
of deep water warming due to the Atlantic layer has almost quadrupled in 20 years.

There are no water areas that have not been affected by human activity, and 40 percent of the world's waters have been severely adversely affected.

Climate change manifests itself on Earth, both in the form of slow global changes and in the form of one-time local weather events. Slow and annually evolving changes - reduction of glaciers, degradation of permafrost, rise in the level of the World Ocean. Locally, there is an increase in the frequency and strength of dangerous hydrometeorological phenomena. Their number has doubled over the past 15-20 years. This means that a similar amount of precipitation falls not in the form of ordinary rains and snowfalls, but in the form of heavy showers and snow storm. More often there are sharp weather changes, storm winds, hurricanes, tornadoes, abnormally high and abnormally low temperatures.

Immediately 300,000 lightning strikes per day were recorded in the Sydney capital city of Australia and in the New Wales state. It sparkled so that even at night it was as bright as day.

The super-powerful over the past 70 years "Mangkhut" Typhoon hits coastal regions of China. The wind, the speed of which reached seventy meters per second, tore houses apart as if they were made of paper. More than 3 million people have been displaced from their homes.

The southern regions of France are declared a natural disaster zone. Heavy rainstorms over the weekend caused the worst flooding in 130 years. Overflowing the banks of the river, they demolished everything in their path. Tens of thousands of houses have been flooded. Major highways were under water, railway traffic was paralyzed.

In Canada, they experienced a rare phenomenon for these places - a tornado. More than 150 thousand people were injured. Crumpled and overturned cars, uprooted trees and houses, barely recognizable in the mass of rubbish are everywhere.

This is only a brief chronicle of extreme climate-related events in the life of mankind, which are periodically repeated in certain parts of the planet Earth and are everywhere accompanied by human casualties. Over the past two decades, about 90 percent of the world's major disasters have been associated with weather events.

As UN Secretary General Antonio Guterres said: "For decades people made war against the planet and now it strikes back."

These are only local weather phenomena, but is the planet Earth approaching a turning point after which irreversible consequences for all mankind may occur, which will turn out to be unexpected, massive and very destructive, the so-called "domino principle" will work. In this regard, I would like to recall the works of Robert May, an Australian scientist, on ecology, devoted to the modeling of unpredictable natural processes using simple equations, which formed the basis of the famous chaos theory. It states that complex systems are extremely dependent on initial conditions and small changes in the environment always lead to unpredictable consequences. This property is also known as the "butterfly effect" and is described in the popular science fiction short story by American writer Ray Bradbury "A Sound of Thunder."

All irrational beings for billions of years of their existence could not (and of course never would have wanted) to inflict even a millionth part of the harm that people have done to Mother Earth, especially over the last 150-200 years, having polluted its seas, rivers, continents, the atmosphere, devastating its bowels, cutting down forests, polluting the soil and water bodies.

"The pollution of the planet is only an outward reflection of an inner psychic pollution: millions of unconscious individuals not taking responsibility for their inner space».

Eckhart Tolle

Who knows if humanity has not laid the foundation for its own destruction? Will it not turn out that the work, genius and dreams of millions, billions of people who lived on Earth were wasted in vain? (Maybe the planet Earth rejects the human way of life).

"People should not forget that they have a very small place on Earth, that they live surrounded by nature, which can easily take back everything that has given to human. It costs nothing to wipe us off from the face of the earth with its breath or flood us with the waters of the ocean - just to remind a person once again that he is not as omnipotent as he thinks."

Ray Bradbury

People forget that the earth, air and water are left to them as if for a while, that other generations will follow, who will also feed on crops from this land and everything should be left to them in a more attractive form.

If nature dies, then a human will also disappear from the face of the Earth, and all material achievements, which a person is so proud of, will turn into fragments that will be overgrown with weeds.

Today it must be admitted that the age of ecological arbitrariness, industrial expansion and uncontrolled population growth has practically brought the Earth to the brink of exhaustion. The high level of industrialization, urbanization and, in general, the technicalization of life leads to the depletion of natural resources and increasingly destructive effect on nature, polluting it and poisoning it with a variety of industrial and domestic waste. Now, when humanity is faced with acute environmental problems associated with the destruction of many species of plants and animals, pollution of natural waters, soil and atmosphere, depletion of landscapes, desertification, depletion of mineral and water resources, destabilization of weather and climate, which led to a critical reduction in vital resources and a decrease in habitat for humans, whether there will also be a question of "climate" refugees.

According to a new analysis by the Institute for Economics and Peace by 2050 year more than 1 billion people will be stranded by environmental threats and the world's rapidly growing population. The world's population is expected to rise to 10 billion by 2050, triggering violent conflicts over water and food. In this regard, about 1.2 billion people in some regions of Africa, Central Asia and the Middle East will be forced to migrate.

One more time we have to remind that the socalled market economy of earthlings is possible only with the constant expansion of sales markets. Planet Earth (the part used is finite, which means the market economy is the basis and foundation of the human consumer society is finite. The situation in the world is such that the existing system of coordinates on the Earth, based on commodity-money relations oriented towards profit, has reached a dead end, leads to degradation or even self-destruction of civilization. The only human habitat in the foreseeable space can be destroyed.

First, people were engaged in gathering and hunting, then farming and breeding domestic animals, 
commodity production, and all this under the plausible pretext that the next generations of people would live better and more conveniently. As soon as a person gets used to a new convenience, which is initially perceived as a luxury and then taken for granted, the rush toward new comforts begins. The pursuit of an easy life has led humanity to a dead end. And all this, in the context of a rapidly growing human population, which, moreover, does not want to live according to the laws of the biosphere, but has created its own artificial environment.

"Give the person what they need and they want the comforts. Provide him with amenities - he will strive for luxury. Shower him with luxury - he will start sighing for exquisite. Let him receive the exquisite - he will crave madness. Give him whatever he wants - he will complain that he was deceived, and that he did not get what he wanted."

Ernest Hemingway.

But folk wisdom about the need to limit one's desires was reflected in the tales of A. Pushkin "About the Fisherman and the Fish", the Brothers Grimm "The Tale of the Fisherman and His Wife", the English folk tale "The Woman Who Lived in a Bottle" which talks about inexhaustible desires old woman, until she demanded too much and in the end found herself at a broken trough. As they say, a fairy tale is a lie, but there is a hint in it, a lesson for good fellows.

"If you wish to make someone rich, do not add to his store of money, but subtract from his desires."

Epicurus

Humanity does not yet think about who it will become and what it will do when it loses everything. What can we say about an ordinary person who, during his fleeting existence, as an intelligent object, often does not have time to understand his true purpose, not to mention more.

"When the last tree is cut down, when the last river is poisoned, when the last bird is caught - only then will you understand that you cannot eat money."

Indian saying

"We can bring salvation to humanity only by our own good behavior; otherwise we will rush like a fatal comet, leaving devastation and death everywhere behind us."

Erasmus of Rotterdam

\section{Part eight}

The coronavirus pandemic has led to the largest education failure in modern history in education worldwide. UN SecretaryGeneral Antonio Guterres notes that the world faced a learning crisis before the pandemic: more than 250 million school-age children in different countries did not have the opportunity to attend school: only a quarter of secondary school students in developing countries graduated with basic essential skills.

"The numbers are striking: every fifth young person does not study and does not work. One in four suffers from violence or conflict. And every year 12 million girls become mothers while they are still children themselves," said Antonio Guterres. "We now face a much larger disaster that could wipe out decades of progress and exacerbate the world's ingrained inequality," he said.
Broken buildings, broken doors and windows. Ruins, porches with unscrewed bulbs. A district of losers, too old or too young. Here, only few boys and girls go to kindergarten or school. Nobody cares about them. Even their parents. They are either unable to help them, or they simply abandon their children. The fathers and mothers of these children are most often illiterate people without a profession and permanent job, and sometimes without a place to live. Such children spend whole days on dusty streets, not childish, without a smile, their eyes look in front of them and with despair of hopelessness. Then they wait. What? Indifference of doom. "Every man for himself" - the well-known formula of life is filled with tragic content.

Old buildings that have not been repaired for a long time, poorly qualified teachers, lack of teaching aids, classrooms packed to capacity. The level of knowledge gained is stunningly low. A child who is starving cannot be a full-fledged schoolboy.

Difficulties in adapting children to living conditions in modern society. The frantic pace of life, the need for an eternal pursuit of success, fierce competition, violence, break, cripple the human psyche. Attempts to adapt, adapt to this life, violence against them lead to severe mental disorders, aggressiveness and outbursts of anger. The dangerous social consequence of all this is the further reproduction of cruelty. Children who meet with various kinds of violence will show cruelty to the weaker in the future.

What is the future for these children? Where is the guarantee that in the near future millions of "nobody's" children - hungry homeless kids - will not turn into sickly, untrained, incapable of serious work - adults, new subpassionarians. A crippled childhood, a twisted life.

And at the top of the educational pyramid in developed countries is education in privileged private educational institutions.

But many of today's children, who are deprived of childhood, will become adults tomorrow and will determine the life of mankind. But it is in childhood, in adolescence that character is formed, the foundations of a worldview are laid. A person's life largely determines by how passed his childhood.

"Did I not live indeed when I learnt to see, to hear, to speak, when I slept, sucked the breast and kissed the breast, and laughed and delighted my mother? I lived and lived gloriously! Did not I then acquire everything whereby I live now? - and did I not acquire so much so quickly, that in all the remainder of my life I have not acquired a hundredth part of what I acquired then? From a child of five to me, as I am now, is but a step. From a new-born child to a child of five the distance is terrific. From the embryo to the newborn - the abyss."

My life. Autobiography. L. Tolstoy

“...The consciousness remaining from animal origin is not capable of more than an act corresponding to its level. If a person is unbridled, then he can commit many acts that are contradictory to human morality. Therefore, a person should be guided by generally accepted laws in his actions. The short meaning of this boils down to the fact that people should live in society and abide by accepted norms.

If we represent society as a single body, then a separate person is, as it were, a separate member of it. And if each member fulfills its intended functions, the body will live, otherwise it will weaken and grow decrepit. Human morality and upbringing are also distinguished from an animal ... Upbringing is divided 
into two types: physical and spiritual. Animals are basically forced to develop themselves physically, that is, take care of the development of their bodies. And in addition to the body, a person also needs to educate his spirit, mind, consciousness, will, character. If in a person the soul and body do not correspond to each other, then he is like a lame ... If the character does not correspond to the mind and physical characteristics of a person, then he has not received a comprehensive education. It is due to insufficient education that theft, deception, murder, robbery and other crimes are found among people.

Human, it would seem, has achieved perfection in everything: he flies like a bird, swims like a fish, brings far distances closer and clarifies the foggy mysteries of nature. And at the same time, he did not part with animal malice, he was killing each other. Why? The fact is that human has not yet become a slave of upbringing, but still remains a slave of nature, i.e. their wild instincts. In this case, how will he be guided by a clear mind and how will the whole society, all people become educated?"

Upbringing. Zhussupbek Aimautov.

"Care should be taken as much as possible to ensure that the art of inculcating morality is properly delivered in schools, so that schools become, as they are called, "workshops of the people."

Jan Amos Comenius

\section{Who moves forward in knowledge, but lags behind morality, goes back more than forward. \\ Aristotle}

In his video message dated April 16, 2020 about the impact of the COVID-19 pandemic on children, UN Secretary-General Antonio Guterres noted that "... I am especially concerned about the situation of children on the planet. ... Their life has changed radically. ... Almost all students do not go to school now. Some schools offer distance learning opportunities, but not all can take advantage of them. Children in countries with slow Internet access and high costs are extremely disadvantaged ... With children out of school, people are isolated, and the global economic downturn is deepening, and family stress is on the rise."

Teachers also caught it bad, they in a short time had to master the functions of programmers, remotely control uncontrollable children, which creates a crisis, especially in elementary school. Moreover, to reflect the aggressive discontent of parents exhausted by unexpected chaos. Parents have conflicts with children, especially adolescents, in the educational process.

With the development of distance education, there are many proposals for its further improvement. Some believe that it is necessary to develop electronic platforms on which bright teachers, high-quality educational content and competent methodological presentation of material are presented. Does this mean that tomorrow the motivated student will go to study with a network educator, and not with his school teacher? There are also suggestions that after quarantine, some items should be left only in digital format. But here I would like to draw the attention of supporters of the introduction of e-learning that a child is socialized at school, in a peer group. And this is an important factor for formation of personalities.

This situation is aggravated by the fact that the standards of secondary general education in different countries differ among themselves.

In the world of pedagogical science, there are two points of view on the content of school education. Supporters of the first direction, the so-called informal, believe that it is necessary for a child to develop logical thinking, develop his ability to analyze, so that he can freely, independently navigate in the information space, and have motivation for self-development.

Here they move away from external assessment of students' knowledge, motivating students to self-assessment, so that children leave school motivated to self-development.

For supporters of the second direction, the so-called formal, students are passive consumers of knowledge, skills and abilities that the educational system transmits to them. The volume of information is increasing and the weekly study load of students is correspondingly increasing, which is currently 358 hours, which is 80 hours more than it was in the 70 s -80 s of the last century.

But there are still homework assignments. And as a result, children have a 10-12 hour working day.

"The young man came to the castle to the sage to find out the secret of success in life. The sage suggested that the young man take a stroll around his palace and come back in two hours' time.

"However, I want to ask you a favor," he added, handing the boy a teaspoon, in which he poured two drops of oil.

"While you walk, carry this spoon and don't let the oil spill."

The young man began to climb up and down the palace staircases, always keeping his eyes fixed on the spoon.

At the end of two hours he returned to the presence of the wise man.

"So," asked the sage, "did you see the Persian tapestries hanging in my dining room? Did you see the garden that the Master of Gardeners took ten years to create? Did you notice the beautiful parchments in my library?"

Embarrassed, the young man confessed that he had seen nothing.

His only concern was not to spill the drops of oil that the wise man had entrusted to him.

"So, go back and see the wonders of my world," said the wise man.

"You can't trust a man if you don't know his house."

Now more at ease, the young man took the spoon and strolled again through the palace, this time paying attention to all the works of art that hung from the ceiling and walls.

He saw the gardens, the mountains all around the palace, the delicacy of the flowers, the taste with which each work of art was placed in its niche.

Returning to the sage, he reported in detail all that he had seen.

"But where are the two drops of oil that I entrusted to you?" asked the sage.

Looking down at the spoon, the young man realized that he had spilled the oil.

"Well, that is the only advice I have to give you," said the sage of sages.

"The Secret of Happiness lies in looking at all the wonders of the world and never forgetting the two drops of oil in the spoon."

Paroemia by Paulo Coelho

The same can be said about the meaning of our children's learning. In fact, it is necessary to move away from the education system, which was sharpened for work in the conditions of an 
industrial order, but in the age of information technologies it simply does not make sense to stuff schoolchildren and students with huge amounts of information. The school must provide a full-fledged, child-developing life at school age. by Paulo Coelho

If we teach today's students as we taught yesterday's, we rob them of tomorrow.

John Dewey

According to the generational theory of William Strauss and Neil Howe, Generation X includes people born between 1961-1981. Generation Y or "millennials" are those who born between 1982 and 2004. Representatives of generation $Z$ have been born since 2005. And each of these generations has its own attitude to education.

Generation $\mathrm{X}$ assumes that knowledge, skills and abilities acquired once and for all remain valid throughout life. For the most part, $\mathrm{X}$ do not strive to continue their education throughout their lives. Training with them is associated, as a rule, with taking advanced training courses at the place of work, or with the need to close gaps in professional knowledge. They are conservative when changing jobs.

Millennials realize that a diploma in itself is no longer a guarantee of a successful career. They regard education not as a formal indicator of status, but look for concrete practical benefits in it. They are more mobile, having gained experience, they easily change the team, environment, place of residence. During the growing up of millennials, the Internet appeared, which opened up access to many opportunities for self-study.

Now the question of choosing an educational model is most acute for the "Z", modern schoolchildren - a generation that has grown completely in the digital environment. Digital technology is so natural for this generation that most of them are familiar with it from childhood. Generation $\mathrm{Z}$ learners are quicker to perceive information from different sources, are able to perform several tasks at the same time, are able to search for information, and switch quickly. The Zetas want to start learning their future profession as early as possible, while retaining the opportunity to change the profile in the learning process.

In this regard, I would like to remind you that in the 70s of the twentieth century, the famous Canadian anthropologist Margaret Mead identified three types of cultures that have a fundamentally different influence on the development of a child.

Postfigurative cultures that have preserved their norms and customs for millennia. Here the child's personality is reproduced in an unchanging way. Upbringing itself is carried out by the elderly and older children who have not yet been involved in productive activities.

Configurative cultures are rapidly changing. Here, each generation differs from the previous one in terms of personality, motivation, and emotional experiences. Although the older generation continues to play a decisive role in education, it is not perceived as an absolute standard.

Prefigurative cultures, the culture of the future, where creativity of the younger generation will act as a support both in teaching and in ethics.

"Your children are not your children. You may give them your love but not your thoughts, for they have their own thoughts. You may house their bodies but not their souls, for their souls dwell in the house of tomorrow, which you cannot visit, not even in your dreams. You may strive to be like them, but seek not to make them like you. For life goes not backward nor tarries with yesterday. They are sons and daughters of Life's longing for itself. You are the bows from which your children as living arrows are sent forth."

Kahlil Gibran

With the development of information technology around the world, standardized testing for assessing educational achievements has become widespread, which causes massive criticism from teachers, educational scientists from all over the world, as evidenced by their letter to the OECD.

"Currently...The Programme for International Student Assessment (PISA) is known all over the world as a tool for comparing OECD and non-OECD countries $(60+-$ at last count) in accordance with the performance of students of age in mathematics, science sciences and reading. The PISA results, conducted every three years, are eagerly awaited by national governments, education ministers and newspaper editorial boards, and have been credibly referenced in countless policy reports. They began to significantly influence educational policy in many countries. PISA has led countries to begin reforming their education systems in the hopes of improving their ranking. The lack of progress on PISA led to the adoption of declarations to deal with the crisis, and also resulted in a "PISA shock" in many countries, followed by resignations and farreaching reforms in line with PISA prescriptions.

To be quite honest about it, we are concerned about the negative impact of the PISA rating. Here are some of the issues that concern us:

- while standardized testing has been used in many countries for decades (despite serious reservations about its validity and reliability), PISA has escalated such testing and increased its dependence on quantitative indicators ...;

- in education policy, the PISA by assessing every three years, draws a shift in focus to address shortterm issues designed to help the country rise quickly in rankings. However, studies show that it takes decades for changes to be made in educational practice to paid off. For example, we know that the status of the teacher and the prestige of the teaching profession have a strong influence on the quality of teaching, but this situation is very different in different cultures and is not easily influenced by short-term policies;

- focusing on a narrow range of measurable aspects of education, PISA diverts attention away from less measurable or immeasurable educational goals such as physical, moral, civic and creative development, thereby significantly narrowing our overall understanding of education and its content;

- ... the new PISA regime, with a continuous cycle of global testing, hurts our children and makes our classroom uninteresting, as it inevitably leads to an increase in the use of multiple-choice tests, automated lessons and less teacher autonomy. In this way, PISA has further increased the already high levels of stress in schools, which undermines the mental health of students and teachers.

These circumstances clearly contradict the widely recognized principles of good educational and democratic practice:

- no reform should be based on a narrow quality indicator;

- no reform should ignore the important role of uneducated factors, among which socio-economic inequality is paramount. In many countries ... inequality has risen sharply over the past 15 years, which explains 
the widening education gap between rich and poor ...;

We write not only to point out flaws and problems. We would also like to offer constructive ideas and suggestions that can help partially solve the problems mentioned above...

We suppose that OECD PISA experts are motivated by a genuine desire to improve education ... The OECD's narrow focus on standardized testing risks turning learning into monotonous work and killing the joy of learning ... We are deeply concerned that assessing the diversity of educational traditions and cultures using one, narrow, biased criteria can ultimately cause irreparable harm to our schools and students.

It is difficult to disagree with this letter.

"...in education, and in every kind of calling the natural sphere of activity is narrowed as far as possible by rules and superintendence. How much less free in many countries is the school teacher of today compared with what he was once! How lifeless and impersonal has his teaching become as a result of all these limitations!". Albert Schweitzer. Culture and ethics.

Of course, you can fill your mind with a lot of different facts, but still not learn anything. Alec Bourne convincingly talks about it in "Too Busy to Live".

To teach a child to highlight the main thing, to see the world universally: in unity and diversity - this is the phenomenon of learning.

It must be admitted that the digital revolution is undermining the methodological foundation of the school inherited from the past. And already on the horizon of 5-7 years, artificial intelligence, which has become generally available and relying on an almost limitless array of cloud educational resources, which, once in the hands of every student, will make a significant part of the current school regulations meaningless. The teacher will not be able to determine whether the student completed the homework himself or whether the electronic assistant did it for him. And how this problem has become aggravated in our time during distance learning. Now it is becoming clear whether we have brought up in our students a genuine interest in learning, motivation to participate in the educational process, practical activities.

Since school days, children are taught only not to think logically, but to cross out the desired answer. Knowledge becomes numb. If they were offered to pass school tests to Pushkin (zero in mathematics), (... all professors looked with awe at Pushkin's growing talent. Mathematics teacher Kartsev, looking at Pushkin, who was silent for a long time at the blackboard: "Well, what is X equal to?" Pushkin - "Zero." Kartsev - "With you, Pushkin, everything ends with a zero in my classroom. Go back to your poems"), Mendeleyev (they did not leave him for the second year or were not expelled for academic failure, out of respect for his father), Einstein (in gymnasium, to put it mildly, he was not very good in academic success) - then all of them would not have passed today's tests. The ability of a student to assimilate ready-made knowledge is very rarely combined with the talent of a creator, a pioneer of something new.

"Understanding is better than memorization, because the action of memorization deals mainly with words and expressions, in other words with details [...], which could go on forever and are hardly useful, neither for individuals nor for classes. [...] But the action of understanding concerns meanings, universals and laws - defined matters, finite, and which are valid for all. To exert oneself in these matters is beneficial. This also applies to the actions peculiar to acquiring them, such as analogy, organization, policies and consideration of the consequences. If the human being learns only the details, he is not secure from going astray. [...] When he relies on principles and general concepts, and when some new matter is presented to him, he may refer to his understanding of the principles to compare one thing with another. So it is clear that understanding is better than memorization."

Al-Farabi. From the treatise "Questions and Answers to Them".

"Learning and not thinking is a waste of time, thinking and not learning is destructive." Confucius

When a bird flies upwards from some place, the wind favors it significantly. If she wants to use it with and to benefit herself, no matter where it was blowing, she is located obliquely in the current of the wind, taking it under her in the form of a wedge, and gives rise to her takeoff, jumping a little.

Leonardo da Vinci

It is necessary to teach the child to fly, and not to force him to guess the species of birds in the test questions. To teach to highlight the main thing, to see the world universally: in unity and diversity, this is the phenomenon of learning.

Children should live in a world of beauty, games, fairy tales, music, drawing, fantasy, creativity.

Vasily Sukhomlinsky

Do not offend children with ready-made formulas, formulas-emptiness; enrich them with images and pictures in which the connecting threads are visible. Don't burden children with the dead weight of facts; teach them techniques and methods to help them comprehend. Don't teach them that benefit is important. The main thing is education in a human being.

Antoine de Saint-Exupery

Since we do not properly imagine what the labor market will be like after the end of the pandemic, and even more so in 2030, we already do not know what to teach our children. Much of what they are currently studying in school, vocational schools will eventually lose relevance. According to world experts, in the near future, the demand for specialists in the humanitarian fields will sharply increase.

"Traditionally, life has been divided into two main parts: a period of learning, followed by a period of working. Very soon this traditional model will become utterly obsolete, and the only way for humans to stay in the game will be to keep learning throughout their lives and to reinvent themselves repeatedly".

Yuval Noah Harari. Homo Deus. A brief history of

Tomorrow.

The rapid pace of life and the accelerated development of technology leads us to the concept of lifelong education throughout life.

Constantly in contact with working people, the system of advanced training and retraining of personnel should respond flexibly to changing working conditions and promptly inform educational institutions about the trends observed in 
labor activities, so that educational institutions make timely adjustments to training programs.

The illiterate of the 21 st century will not be those who cannot read and write, but those who cannot learn, unlearn, and relearn.

Alvin Toffler

As noted above, the school curriculum is overloaded. Yes, knowledge becomes more complicated, the amount of information falling on a person becomes an avalanche. But, it is unlikely that this problem can be solved by increasing the period of study, introducing more and more narrowly focused subjects that are little related to each other.

Many schoolchildren are no longer able to master the proposed programs, and this leads to the fact that they lose interest in learning, consider themselves to be losers. Will this not lead them to subpassionarity in adulthood?

The structure and content of the secondary school curriculum should be determined on the basis of a systematic generalization of data from the fundamental sciences. Textbooks should develop in the student an understanding of the development of humanity through a critical analysis of its largest phenomena.

"...Narrow specialization is only useful as a means of accumulating knowledge. The differentiation of disciplines was a stage, necessary and inevitable, that inevitably becomes disastrous when dragged out for a long time. Accumulation of information without its systematization into an object of broad generalization is a quite senseless task".

Ethnogenesis and the Biosphere of Earth. Lev

Gumilyov

We have to get away from multidisciplinary. In the prepared textbooks, interdisciplinary communication should be strengthened. Ethics, aesthetics, cultural studies should become an integral part of the school curriculum. The ecological component should be a common thread in all textbooks. Today, we must understand that when teaching our children, whose future we endlessly value, it is necessary to strengthen the humanitarian component. It is humanitarian knowledge that makes it possible to overcome technocratic and narrow professional thinking, educate a spiritually rich person, focused on universal human values, with a developed sense of moral responsibility.

"In modern teaching and in modern school textbooks, humanity is pushed into the darkest corner, as if it has ceased to be the truth

Albert Schweitzer. Culture and ethics.

Today the issue of hygienic education at school has become acute. And this is not just washing hands, it is posture, myopia, abnormalities in the cardiovascular system, neuropsychiatric disorders. School neurosis is the fault of teachers and parents who do not take into account the peculiarities of adolescence, which Jean-Jacques Rousseau called "a period of storms and passions." The health of the students is no better.

The content and forms of teacher training are in need of fundamental changes. Future teachers need to be trained in medical and psychological literacy. They must have a high culture and morality. We need psychologists-pediatricians, psychologists-teachers. Distance learning has shown that not only children, but also parents need the help of teachers. It is necessary to organize parental education in a proper way.

\section{Part nine}

The future comes without greeting.

According to UN Secretary General António Guterres, one of the four horsemen of the Apocalypse threatening the world is the "dark side of the digital world".

Until today, despite all the efforts and achievements, which often went to the detriment of the surrounding biosphere, humanity has acted within the framework of the laws established by biology. Currently, Homo sapiens is taking measures to finally renounce kinship with nature, creating its own artificial environment, the logic of behavior inside which fundamentally contradicts the surrounding biosphere.

With the same frenzy, as before, man moved away from nature, and now, he moves away from each other, fencing his mind with a palisade of protruding facts, terms and numbers.

In the ancient world, the Tower of Babel became a symbol of the separation of peoples living on Earth, whether gadgets will become a symbol of the separation of people.

The capabilities of the human mind have a limit, it is not able to assimilate more than a certain amount of information. At the same time, the amount of information consumed for each person is growing by an average of $5.4 \%$ in year.

Gadgets have drowned out live human speech, made conversation and reflection inconceivable. The digital epidemic has hit humanity. Gadgets wean people off thinking. In any difficulty, people grab onto a smartphone connected to the Internet, like a saving straw. The human brain adjusts to new needs. Now the main thing is the ability to filter out unnecessary information. Determine what is paramount and what is secondary in the flow of news and information. The old classical conceptual thinking, when it was important to understand the essence of things, is an outdated option today. It too "slows down" the process of processing a huge amount of information that falls on humanity from TV and radio broadcasts, the Internet, newspapers, social networks, sms - messages and e-mail. To protect itself from information overloads, the human brain took the path of clip thinking, that is, it began to look for ready-made answers on the Internet for every difficulty.

Even today, doctors say that more and more children suffer from disorders of attention, memory and thinking. There is only one reason: passion for gadgets. According to scientists, the radius of activity of children since 1970 has decreased by $90 \%$. Children, instead of outdoor games on the street, were carried away by computer games, while the growing brain needs as many external stimuli as possible to develop in order to learn how to make decisions, empathize, and control their actions.

\section{They do not see and do not hear Living in this world like in the dark \\ For them, the suns, know, do not breathe, And there is no life in the sea waves.}

Fyodor Tyutchev

On the one hand, it seems that the new generation is simply more practical than the previous ones, because it does not spend energy and time looking for answers to the questions that arise, but on the other hand, who will generate new ideas and unravel complex problems, if they are with their clip thinking and will slide over the top? It is just some kind of superficial, shimmering knowledge that is not embedded in the depths of the soul.

In truth, the Internet has everything or almost everything, and what is needed and not needed, and every day this bottomless 
library is replenished .. Here you can find a lot that a person needs, but with a little clarification: the Internet does not know everything, it only stores it everything. And the keys to this repository lie in education. For if a person is not educated, then he simply does not know what to look for, where to click.

Cram them full of noncombustible data, chock them so full of 'facts' they feel stuffed, but absolutely 'brilliant' with information. Then they'll feel they're thinking, they'll get a sense of motion without moving...

Ray Bradbury

I would not like Aldous Huxley to be right, who in his novel Brave New World (1932) suggested that there simply will be no one left on Earth who would like to read, and that people will drown in the ocean of information and become lazy and selfish.

Language is the form in which the stock of information is stored. The manifestations of the spiritual culture of mankind were preserved through oral folk art. The growing volume of information, the need to preserve it in time (for future generations) and transmit it in space (to people in another place) led to the invention of writing. Then came the time of radio, television, the Internet. It would seem that humanity has everything in its hands for its spiritual enrichment.

"When one is writing a letter, he should think that the recipient will make it into a hanging scroll"

Yamamoto Tsunetomo

Unfortunately, the word is currently being devalued on Earth. In the huge volume of information flow falling on each person, there are more and more rumors, so-called sensations, scandals, gossip. This phenomenon, which is called the Boulevard Press, has become characteristic of many mass media on Earth and claims to be the leader in the formation of certain worldview models in the consciousness of mankind that run counter to human natural needs.

In the words of Samuel Johnson, "language is the clothing of thoughts." I don't want to believe that these are the thoughts of modern mankind.

Since the beginning of the pandemic, the role of social networks has increased many times over, thanks to which people keep in touch with each other and receive reliable information. But along with reliable and useful information, "outright lies are spreading on the Internet at a terrifying rate," said Antonio Guterres. "A recent analysis of one of the largest social media platforms showed that 40 percent of posts related to COVID - 19 were generated by bots - automated programs disguised as specific people." remain.

The word will lose its meaning, only a shadow will

... And your tongue will be gnarled, motley. Kazakh sage-seer Monke bi. XVIII century.

Paraphrasing the famous phrase of Fyodor Dostoevsky from the novel "The Idiot" that "Beauty is a terrible and awful thing!... we can say that the Word is a terrible and awful thing! We must take care of the word, its sacred meanings, its role in the life of a person and society.

"The word can become a drop of moisture in the beak of a swallow, wishful to put out the fire of discord, or it can be a straw of a raven thrown into this fire."

Kazakh folk wisdom
Whether we want to admit it or not, the facts indicate that today in the world there is a deliberate lowering of the spiritual level of mankind, which results in increasing social vices.

A culture that should educate a person on lofty ideals, on values that have preserved the life of mankind for centuries, focuses primarily on the market, on consumer success, where vulgarity, pathology, and permissiveness are at a premium. And on all this we are raising the younger generation, in whose heads there is a reassessment of values by no means for the better.

Probably, there is a need for censorship in human society, in all states under whatever laws and government they are. And don't be afraid of that. The word "censorship" is translated from Greek as "strict judgment, exacting criticism." Is it possible that humanity, caring about future generations, does not have the right to strict judgment. Back in the XIX century, Gogol said "... now there is a battle, the most important battle is the battle for our souls." Now, in the XXI century, are we losing this battle?

Video games, which have become a billion-dollar business in which everything is focused on making the final profit, and few people pay attention to their content.

Addiction to computer games is a new type of psychological addiction, in which a computer game becomes a leading human need and, according to psychologists, this type of addiction is much more dangerous than alcohol or drug addiction. The statistics of psychologists on the prevalence of this dependence differs among different researchers: from $10-14 \%$ to $40-80 \%$. Psychologists are united in one thing - the number of people addicted to computer games is increasing every year, and the age of those who play is decreasing. More than 3.1 billion people around the planet are addicted to video games, according to research firm DFC Intelligence. The number of people addicted to video games has increased dramatically in recent years due to the widespread adoption of smartphones.

Meanwhile, manufacturers of gadgets, computer games and other entertaining "stuffing" involve psychologists in the development of their products, who come up with new tools to capture human attention.

\section{The hymn of gambler}

... She never vexed me nor was angry with me, but was ever gracious to my friends and me.

For a dice which scored one too much, I drive away my own devoted wife.

... The gamester seeks the gambling-house, and wonders, his body all afire, "Will I be lucky?"

The dice run against his desire, giving the best throws to his adversary.

... The gambler's wife is left forlorn and wretched: the mother mourns the son who wanders homeless.

In constant fear, in debt, and seeking money, he goes by night to the home of others.

From Old Indian "The Rig Veda"

The mechanism for the formation of computer addiction is based on a departure from reality, and as the addiction progresses, the social, labor and family adaptation of a person is disrupted - he forgets about office, household chores, about study, loses interest in them, social adaptation is disrupted, material problems arise associated with the need to pay to participate in a number of games. 
The presence of psychological addiction is also reflected in the habits of a person who more and more often eats without leaving the monitor, neglects personal hygiene, reduces physical activity to an unacceptably low level and, as a result, a complex of problems associated with his physical condition.

"The Internet is so big, so powerful and pointless that for some people it is a complete substitute for life." Andrew Brown

Technological progress has completely changed the world, and human perception of the world. If earlier a person looked at the world with wide, enthusiastic eyes, today all perception goes through gadgets. Will this not lead to the fact that people, overloaded with facts, haphazard fragmentary knowledge will increase the feeling of loneliness, decrease the ability to compassion and love. Game "Blue whale"

They neither see nor hear

They live in this world, as in the dark,

For them, the suns, to know, do not breathe, And there is no life in the sea waves.

The rays did not enter their souls, Spring did not bloom in their chest, With them the forests did not speak And the night was dumb in the stars!

\section{And with tongues unearthly, Exciting rivers and forests I didn't consult with them at night In a friendly conversation thunderstorm!}

\section{It's not their fault: understand, if maybe Organa life is deaf and dumb! \\ Soul him, ah! will not alarm}

And the voice of the mother herself!

Fyodor Tyutchev

Currently, humanity, moving to a post-industrial civilization, has begun to implement the fourth industrial revolution, the main features of which are the mobile Internet, miniature manufacturing devices, learning machines and artificial intelligence, unfortunately, without learning from the past, without revising their views on the world around us and on himself, without having developed moral, ethical and legal norms that are binding on all mankind.

Founder and President of the World Economic Forum in Geneva, Switzerland, Klaus Schwab, in his book "The Fourth Industrial Revolution" notes that "the current level of management and awareness of current changes in all areas is extremely low in comparison with the need to rethink economic, social and political systems in order to meet the challenges of the fourth industrial revolution. He believes that "along with contextual and emotional intelligence, there is also a third critical component that will effectively pave the way for the fourth industrial revolution. He calls it "the inspired mind." ... "Inspirational mind is aimed at a continuous search for meaning and purpose. It focuses on the nourishing creative impulse that lifts humanity to a new collective and moral consciousness based on a shared sense of destiny ... we run the risk of not coping with the challenges of the fourth industrial revolution, or not taking full advantage of the benefits that it could give us if we do not develop in ourselves a sense of a common goal ".

In this regard, now on earth there is no shortage of discussions, statements that are often contradictory on this issue.
Some believe that artificial intelligence threatens humanity, is the main existential threat and expresses fears that machines capable of surpassing humans will be created in the near future. In turn, others point out that the problem of controllability of artificial intelligence should not bother a person. Development will take place only at the level at which a person will allow, and the degree of freedom of an artificial mind is also completely dependent on people.

Both those and others note that artificial intelligence will increasingly be integrated into all spheres of life, production will become more efficient, which means less labor will be required. However, on the question of whether this will entail mass unemployment or not, opinions vary - from encouraging to pessimistic.

“... In the XXI century we can witness the emergence of a multimillion non-working class: people deprived of any economic, political or even cultural value.

... The coming technological prosperity will obviously allow to feed and maintain these useless masses without demanding anything from them in return. But what to do with them and how to make them content with what they give? People have to do something, or they go crazy. What will they be doing all day? One of the options is drugs and computer games. Unnecessary people could hang out in $3 \mathrm{D}$ virtual reality, much more exciting and exciting than their gray days.

Some experts and thinkers, including Nick Bostrom, believe that we are not in danger of such degradation, since, surpassing human abilities, artificial intelligence is likely to simply destroy all of humanity. He will do this either out of fear that humanity will rebel against him and try to "pull the cord out of the socket", or in pursuit of some of his own incomprehensible goal. For people will find it incredibly difficult to control the motivation of a system smarter than themselves ... Powers will completely pass from human beings to highly intelligent algorithms ... Yuval Noah Harari. Homo Deus. A brief history of Tomorrow."

Scientific discoveries in the field of technology allow a person to obtain the greatest results at the lowest cost. Already simple tools of production - a spade, an ax, a hammer, a forge, a spindle, a lever, a gate, a wheel - gave albeit small, but labor productivity. Then man began to use the power of tamed animals, and then the forces of nature to set in motion the tools of production. Sails and windmills appeared. Then technology began to develop faster and faster. Cars, trains, airplanes, radio, television, spacecraft, nuclear power plants, computers, microelectronics.

At first, a person transferred his physical skills, hand skills to technology, and now, through artificial intelligence, he transfers the skills of the human brain.

But here we would like to draw the attention of mankind to the following. In the XIX and XX centuries, the development of technology during the industrial revolutions proceeded in a direction set by man and was controlled. At present, the technological revolution is ahead of man. Suffice it to say about the Internet, which ten years ago was hardly noticeable. Today, without cyberspace, neither everyday life, nor the economy, nor the safety of earthlings is unthinkable. Who regulates cyberspace today? In fact, the Internet has become a free, unlawful zone that ignores borders, abolishes privacy, and is the most serious threat to global security.

\section{Conclusion}

The COVID-19 pandemic has shown that a disaster can come out of nowhere, clearly demonstrating our vulnerability 
and unpreparedness. Both land and sea, on which nearly 8 billion earthlings live, expect intelligent deeds and accomplishments from people. Nature has already swallowed plenty of poisonous fumes and stale waters, it is time to turn to the paternal shelter and build your home with the whole world in accordance with common sense.

It is clear that the pandemic will pass, the question is when and at what cost. At the end of the pandemic, it will be necessary to solve the tasks that this coronavirus epidemic has revealed to us.

The world today. This is not only the world of cars, airplanes, automatic lines, digital technologies, radio telescopes that capture the pulsation of unimaginably distant galaxies. Most importantly: the world of today is the world of the human soul, anxious, doubting and vulnerable. Seeking the truth, suffering from lies and injustice.

The world is in turmoil, and there is a great need for kindness. The mind should be well aware of what it is doing.

Time has exposed a gap, dangerous for the fate of civilization, between the technical power of man and the level of development of his social consciousness, his morality. It is this gap that is one of the causes of the nuclear threat hanging over the world, environmental and food and other global problems.

It cannot be said that humanity does not understand the threat hanging over it. Mankind has finally come to understand the fact, absolutely obvious to any unreasonable animal, that in order to live, one needs a habitat. People began to understand that the Earth is suffocating and is gradually dying under the weight of the offspring of human activity. This topic has long gone beyond the scope of discussion in political and scientific circles, it worries every inhabitant of the planet Earth, as evidenced by the words of Leonardo Wilhelm DiCaprio: “... Climate change is real; it is happening right now. It is the most urgent threat facing our entire species, and we need to work collectively together and stop procrastinating. We need to support leaders around the world who do not speak for the big polluters or the big corporations, but who speak for all of humanity, for the indigenous peoples of the world, for the billions and billions of underprivileged people who will be most affected by this, for our children's children, and for those people out there whose voices have been drowned out by the politics of greed."

On August 26, 2019, at the G7 Summit in France, UN Secretary General Antonio Guterres declared a Climate Emergency and called on the G7 leaders to save the planet.

On November 6, 2019, the world media reported that more than 11 thousand scientists from 153 countries of the world signed the document stating that indescribable suffering awaits Humanity if urgent measures are not taken to reduce carbon dioxide emissions.

The situation with climate change is so serious that it requires the most urgent measures and the European Parliament agreed with the opinion of scientists, which adopted a resolution on the Emergency Situation in the Field of Climate and Environment in Europe and on the planet in Strasbourg on November 28, 2019.

On December 15, 2019, the participants of the 25th UN World Conference on Climate Change (COP 25) adopted a final statement according to which states must raise their climate goals above the bar. As UN Secretary General António Guterres said: "For decades people have been at war with the planet and now it is striking back."

UN Secretary General Antonio Guterres, speaking at the UN General Assembly, with a report on the results of the organization's work in 2019 and tasks for 2020, said that there are currently four "horsemen of the Apocalypse" threatening the world.

The first horseman is "the highest geostrategic tension." The UN Secretary General stressed that destructive conflicts lead to widespread human suffering.

The second rider is the climate crisis. Antonio Guterres drew attention to the fact that there is an increase in the average temperature in the world, millions of species of living creatures are under threat of extinction.

The third horseman Antonio Guterres called "growing global mistrust", two out of three people live in countries where inequality is growing; more and more people are questioning the benefits of globalization.

The fourth horseman, according to the UN Secretary General, is the "dark side of the digital world".

In his opinion, "these four horsemen ... can jeopardize every aspect of our future."

The changes taking place in our life are a consequence of our choices and our decisions. Wisdom of the Ancient East

In practice, modern human civilization is balancing on the brink of the permissible. For too long people have focused on profit, wealth, power, shifting from one generation to another, the solution of problems to save humanity.

"Most of our troubles originate from afar, from one or another of our ancestors, who were destroyed by their own excesses. We are punished for his intemperance: there is no need to drink - he has already drunk everything for us. The hangover that amazes us so much is the price we pay for its euphoria."

Confessions and curses. Emil Cioran

You can't put off further. Of course, many problems have accumulated, and mankind itself knows about them, but without losing their heads, leaving aside all political differences, today (tomorrow it may be too late) all earthlings, regardless of gender, age, race, religion, need to unite and apply everything. efforts to save the remnants of the planet's ecological system and ourselves. Even despite the fact that, according to Anna Akhmatova,

Everything is plundered, betrayed, sold, Black death flashed a wing, Everything is consumed by hunger longing, Why did it become light for us?

Cherry breaths in the afternoon

An unprecedented forest under the city, At night shines with new constellations The depths of the transparent July skies, -
And the miraculous comes so close
To the dilapidated dirty houses ...
Nobody, nobody knows
But from the ages we have desired.

The future is today.... There is no tomorrow. The day of man's salvation is now.

Dale Carnegie

The Australian Commission on the Future of Humanity, in April 2020, identified 10 potential catastrophic threats. Risks 
that have equal degree of import;

1. Reduction of natural resources, especially water resources;

2. Destruction of ecosystems and loss of biodiversity;

3. Growth of the population in excess of the "abilities" of the Earth;

4. Global warming and anthropogenic climate change;

5. Chemical pollution of the earth system, including the atmosphere and oceans; quality;

6. Rising food insecurity and deteriorating nutritional

7. Nuclear weapons and other types of weapons of mass destruction

8. Pandemics of new and incurable diseases;

9. The emergence of powerful, uncontrollable technologies;

10. National and global failure to understand these risks and take preventive action.

The Commission notes what humankind will do with these 10 threats to existence in the next few years, will determine what awaits current and future generations: a safe, sustainable and prosperous future or the prospect of collapse or even extinction. This is a choice that we must make together.

"If we don't act now, this century could be the last century of humanity," warns UN Secretary-General Antonio Guterres.

Humanity is at a crossroads: one path leads to despair and hopelessness, the other one to selfdestruction. Let's hope that we instinctively choose the right path.

Woody Allen

At such a moment as today, we are not faced with any national tasks - we are all people, we all live in the same world. The pandemic has made everyone equal, regardless of nationality and social level. So, really, in order for people to feel that they are a huge global family, a tragedy of this level was needed?

"In order to understand something, a person needs to survive a catastrophe, pain, poverty, the nearness of death".

Erich Maria Remarque

What can save. Belief is the best and justice. All over the world there should be uniform moral foundations. As Jeremiah Bentham once noted, this is about creating a kind of "moral arithmetic" that will be entrusted with calculating the useful effect of all decisions made, and the principle of the maximum possible happiness for as many people as possible should apply to everyone and give a reliable and accurate orientation in matters of good and evil.

Today we need to understand that after the cruel, and for many, tragic blow of the coronavirus, life cannot be the same as before. Much will become different, much will have to be rethought. It is very important that not only medical, financial and organizational lessons are learned from the current dramatic situation. Much will become different, a lot will have to be rethought, felt, look at the universe as if it had been seen for the first time. Spiritual movements directed towards the inner world gave people the opportunity to survive in the most difficult times. Maybe this is how the Renaissant-human begins.

"While other animals look downwards at the ground, he gave human beings an upturned aspect, commanding them to look towards the skies, and, upright, raise their face to the stars".

Metamorphoses.

"The God put a man on two legs so that he was tall, He has placed man's head high so as to enable him to behold the surrounding world...

Human does not crawl on all fours, as the beasts do, to get his food, but brings it to his mouth with his hand...A man's face is beautiful".

Abay. Words of edification.

Time and space separates the authors of these lines. One ancient Roman poet who wrote "Metamorphoses" at the beginning of the I century $A D$, which is the most significant of his works, another one Kazakh from Central Asia, who wrote "Words of Edification" in his declining years, at the beginning of the $X X$ century $A D$, who already knew the temptation of power and hardships of earthly affairs, recognition of the people and the loss of loved ones.

It's time for the man to raise his head. Open the dark and deserted streets of your mind to the light of the sun and populate them with thoughts, see a moment of captured beauty, hear the sound of a spring. We hope that humanity will be wise enough never to let such moments slip away.

Reconsideration should touch primarily the foundations of the civil, political and moral life of mankind. It is necessary to get rid of everything that is false, false, superficial and, first of all, get rid of an arrogant attitude towards nature.

Before it is too late for people, it is necessary in new conditions to determine their meaning of life, which is one of the fundamental philosophical problems and the content of which is to understand the ultimate goal of human existence, to determine its place in nature as a biological species and destiny as a social being.

The story is written so that, after all the disorder, a person finally learns that the happiness of his family is based not on arbitrariness, but on the natural law inherent in it: on mind and justice.

Johann Gottfried Herder

It is necessary to move away from human despair, which give rise to the contradictions of the crisis era. An organism called the Earth is sick, and seriously sick, there is an inflammatory process caused by the actions of "intelligent" people living on it. At present, the unity of all mankind is needed more than ever. To not work like Winston Churchill: It is necessary to move away from human despair, which give rise to the contradictions of the crisis era. An organism called the Earth is sick, and seriously sick, there is an inflammatory process caused by the actions of "intelligent" people living on it. At present, the unity of all mankind is needed more than ever. Whatever happens, as in Winston Churchill: "Humanity is like a ship in a storm. The compass is damaged, nautical charts are hopelessly out of date, the captain has been thrown overboard, and the sailors must replace him in turn. Moreover, each turn of the rudder has to be coordinated not only with the crew members, but also with the passengers, who are on the deck every minute more".

Speaking on September 22, 2020 at the 75th session of the UN General Assembly, UN Secretary General Antonio Guterres called the coronavirus pandemic "the fifth horseman of the apocalypse" threatening the modern world, along with geostrategic tensions, the climate crisis, 
global mistrust due to inequality, negative effects of digital technologies while emphasizing: "People are suffering. Our planet is on fire. Our world is struggling to cope with the situation, is under stress and needs real leadership and action."

The main task for all people is not to find out who is better or worse, but to grope what unites them, in order to reach out in time or accept it in response ... Is it naive? Maybe. But if people perceived with their hearts this simple principle here and now, many conflicts and contradictions could be resolved peacefully.

\section{"Man is my name, German is my moniker."}

\section{Adolf Diesterweg}

Each person needs to start with himself, to recover in particular and to help the body (Earth) to find health as a whole, by reconsidering his attitude to the world and starting to think and act in a creative direction.

After all, if I don't burn,

And if you don't burn

And if we don't burn,

So who will dispel the darkness here?

Nazym Khikmet

Speaking about the further development of mankind, I would like finally people on planet Earth to realize that a human is something more than just a tool for extracting profit from the universe and which, in order to survive, must coordinate its activity with the laws of the biosphere, a particle (and not lord) which he is.

People need to understand that the main motive for human activity should be self-realization, not self-interest. Without posing these key questions, and continuing the usual path to profit, but under different conditions, humanity with all the new technologies that in themselves pose a certain threat to it, can find itself in a difficult situation. In order to survive, humanity must move to creating a society that focuses on natural and environmental safety, rather than economic growth as the main indicator of success, which in turn will lead to the fact that the economic way of life on Earth based on the so-called market economy, in based on which only profit will come to its logical conclusion. How painless the exit of humanity from this system and the transition to a more just society will be depends on it.

Whether it wants it or not, in order to save itself, humanity must return to the laws of nature and reason, re-creating itself, extinguishing greed, self-will and indifference in itself - until the last hope of human existence remains.

"As human beings, our greatness lies not so much in being able to remake the world - that is the myth of the atomic age - as in being able to remake ourselves." Mahatma Gandhi

P.S. Certainly, governments and international organizations are taking measures to stabilize the situation, but without the perception by every inhabitant of the Earth of the crisis situation experienced by human civilization, it is difficult to count on overall success.

Despite numerous dire predictions, everything can change if the correct messages are broadcast to the population of the Earth, and we hope that this book will be supplemented with the folk wisdom of people from all over the world. Each nation has personalities who are a kind of ethical and moral fork, who not only preached high principles, but also lived by them. 